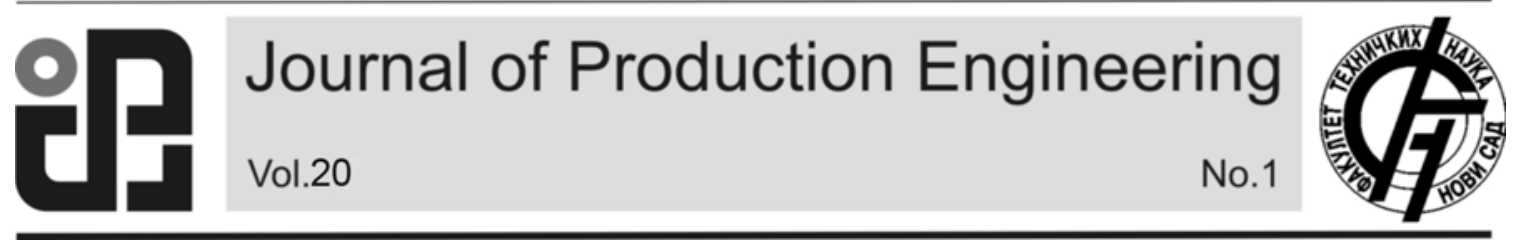

JPE (2017) Vol.20 (1)

Khanna, P., Maheshwari, S.

Original Scientific Paper

\title{
MICROHARDNESS ANALYSIS IN MIG WELDING OF STAINLESS STEEL 409M
}

Received: 14 March 2017 / Accepted: 17 April 2017

Abstract: Stainless steel 409M is a utility grade ferritic steel and was developed as a cheaper alternative to Austenitic stainless steel as it has less amounts of Ni, but still posses very good corrosion resistance, mechanical properties and weldability. In the present investigation, effect of heat input and cooling rates on the magnitude and distribution of microhardness values in different weld zones developed during the MIG welding of this material have been studied and analyzed. A weld can broadly be divided into four main zones namely; fusion zone (FZ), weld interface or fusion boundary zone (FBZ), heat affected zone (HAZ) and unaffected base metal zone. These zones experience different rates of cooling, resulting in the formation of different microstructures. Microhardness study is one of the methods of testing the quality of a weld as it enables the mechanical properties to be determined in different weld zones by corroborating the nature of microstructure constituents present therein.

Keywords: microhardness, fusion zone, fusion boundary zone, heat affected zone, microstructure

Analiza mikrotvrdoće MIG zavarivanja nerđajućeg čelika 409M. Nerđajući čelik 409M je konstrukcioni ferritni čelik $i$ nastao je kao jeftinija alternativa austenitnnog nerđajućeg čelika, jer ima manje količine Ni, ali $i$ dalje poseduje veoma dobru otpornost na koroziju, mehanička svojstva i zavarljivost. U ovom istraživanju je proučavan $i$ analiziran efekat unete toplote i hlađenja na veličinu i distribuciju vrednosti mikrotvrdoće u različitim zonama šava razvijenih u MIG zavarivanju ovog materijala. Zavar se može podeliti u četiri glavne zone naime; zona fuzije zavara (FZ), interfejs ili granična zona fuzije (FBZ), zona uticaja toplote (ZUT) i zona osnovnog metala. Ove zone su pod razlicitim uticajem toplote $i$ hlađenja, što dovodi do formiranja različitih mikrostruktura. Studija mikrotvrdoće je jedna od metoda ispitivanja kvaliteta vara jer omogućava da se mehanička svojstva utvrde u različitim zavarenim zonama potkrepljena prirodom mikrostrukture sastojaka prisutnih na njima.

Ključne reči: mikrotvrdoća, zona fuzija, zona granice fuzije, zona uticaja toplote, mikrostruktura

\section{INTRODUCTION}

In a fusion welding process, the rate of cooling is of prime importance as it decides the kind of phase transformation that takes place at a given point. The rate of cooling further depends upon the welding process, welding procedure, weld parameters, weld metal etc. MIG welding process is capable of welding all metals for which electrode wires are available [1]. Selection of welding parameters has a significant effect on the resulting microstructures [2, 5].The different weld zones formed are shown in fig.1 $(\mathrm{a} \& \mathrm{~b})$. The rate of cooling decreases as the distance from the weld centreline increases, which suggests schematically that different phase transformations will take place in different zones. MIG welding is a high cooling rate process where the heating and cooling of the weld and the base metal are so fast that it is not always possible to predict as to what extent a particular phase transformation has taken place [3]. The FZ is characterized by a homogeneous mixture of base and filler metal and has columnar structure. It exhibits a typical cast structure. The weld interface or FBZ is a narrow zone consisting of partially melted base metal which immediately solidified before any mixing could take place. HAZ is where the heat from the welding causes heat treatment of the parent metal. The amount of metallurgical damage is decided by the maximum temperature reached, distance from FZ, time of exposure to maximum temperature, cooling rate etc. HAZ exhibits heat treated structure involving phase transformation, recrystallization and grain growth [4]. The unaffected zone is the region where heat from welding could not bring about any phase change as the temperature here stays less than the recrystallization temperature. In order to differentiate one transformation from the other, microhardness survey of different zones of interest is carried out [6].

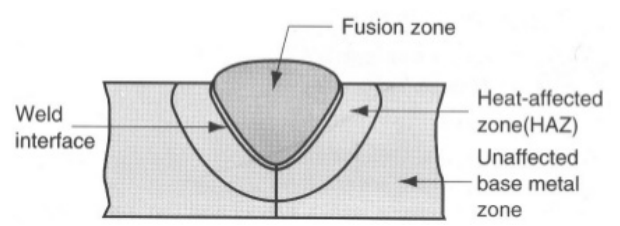

Fig. 1(a) Different weld zones

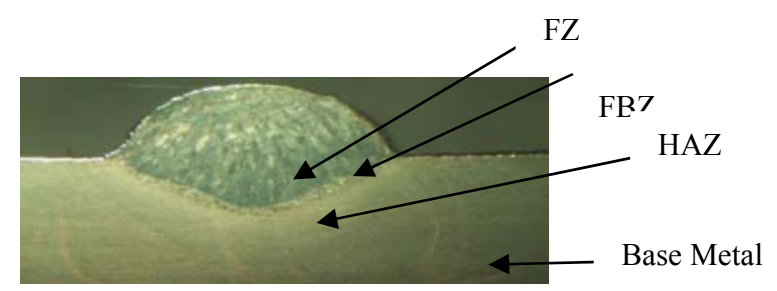

Fig. 1 (b) Actual weld photograph

\section{EXPERIMENTAL INVESTIGATIONS}

A detailed microhardness survey was carried out in various weld zones shown in fig. $1 \mathrm{a} \& 1 \mathrm{~b}$, to ascertain 
the effects of following weld parameters on microhardness.

1. Effect of wire feed rate

2. Effect of arc voltage

3. Effect of welding speed

4. Effect of nozzle to plate distance

5. Effect of torch angle

The working limits of weld parameters are shown in table-1. The standard bead on plate technique was used to lay the weld beads on SS409M plates of $250 \mathrm{mmx} 150 \mathrm{mmx} 6 \mathrm{~mm}$ size with a wire of $\varnothing 1.2 \mathrm{~mm}$ of Stainless steel 308L. Single beads were laid lengthwise at the centre of each plate. Specimen of $25 \mathrm{~mm}$ width each were cut from the middle of each plate and were polished as per the standard metallurgical practices and etched using a recommended etchant, a mixture of Ferric chloride, Hydrochloric acid and water in this case.

The microhardness value of the parent metal was determined (as per ASTM E834) separately and was superimposed on the graphs depicting the microhardness values fusion zone, fusion boundary zone and heat affected zone. Microhardness values of all the samples were determined by using Vickers microhardness tester of make Future Tech, model FM$700 \mathrm{e}$, in two directions, one along the horizontal axis parallel and near the surface of the plate and the other along the vertical axis, starting from the centre of the weld bead towards HAZ as shown in figure 2 (a \&b). The results were graphically plotted to clearly understand the effect of different weld parameters on microhadness values in various weld zones.

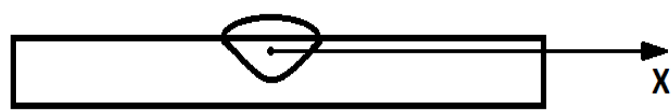

(a) horizontal axis

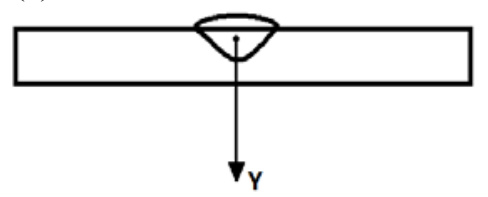

(b) vertical axis

Fig. 2. micrhardness along

\begin{tabular}{ccccccccc}
\hline Welding variables & Unit & \multirow{2}{*}{ Symbol } & \multicolumn{5}{c}{ limits } \\
\cline { 5 - 8 } & & & -2 & -1 & 0 & 1 & 2 \\
\hline Wire feed rate & $\mathrm{m} / \mathrm{min}$ & $\mathrm{I}$ & 2.8 & 4.8 & 6.8 & 8.8 & 10.8 \\
Welding speed & $\mathrm{cm} / \mathrm{min}$ & $\mathrm{S}$ & & 30 & 35 & 40 & 45 & 50 \\
Arc voltage & volts & $\mathrm{V}$ & 20 & 23 & 26 & 29 & 32 \\
Nozzle to plate distance & $\mathrm{mm}$ & $\mathrm{N}$ & 10 & 12.5 & 15 & 17.5 & 20 \\
Electrode to work angle & degrees & $\theta$ & & 75 & 82.5 & 90 & 97.5 & 105 \\
\hline
\end{tabular}

\section{RESULTS}

The results in the form of microhardness graphs are presented in figures 3-7. Each of these figures has two parts (a) and (b). Part (a) represents the microhardness values along the horizontal axis parallel and close to the workpiece surface. and part (b) shows microhardness values along the vertical axis of the weld bead. Microhardness values of the parent metal have been superimposed in each figure for comparison.

\section{ANALYSIS OF RESULTS}

The graphical results are analyzed to understand the effects of various welding parameters on the microhardness values in different zones as given below;

\subsection{Effect of wire feed rate}

The microhardness values along the horizontal andvertical axes of the weld are shown in Figure 3 (a \& b). It shows that the microhardness was much higher in the fusion zone and dropped suddenly at the fusion boundary zone to nearly the same value as that of parent metal. The wire feed rate of $2.8 \mathrm{~m} / \mathrm{min}$ consistently showed higher values than at $6.8 \mathrm{~m} / \mathrm{min}$ and $10.8 \mathrm{~m} / \mathrm{min}$ in the fusion zone. The reason may be that at lower values of WFR, the cooling rate is faster.

\subsection{Effect of welding speed}

Figure 4 (a) and (b) shows the microhardness values along the horizontal andvertical axes of the weld respectively. Microhardness is maximum at a welding speed of $50 \mathrm{~cm} / \mathrm{min}$, which is indicative of the fact that at higher welding speeds due to faster cooling rates, a hard microstructure is formed.

\subsection{Effect of arc voltage}

Figure 5 (a) and (b) shows the microhardness values along the horizontal and vertical axes of the weld respectively. It is evident that the microhardness is maximum at an arc voltage of $20 \mathrm{v}$ and minimum at $32 \mathrm{v}$. The change in microhardness with voltage could be attributed to the change in arc spread with voltage.

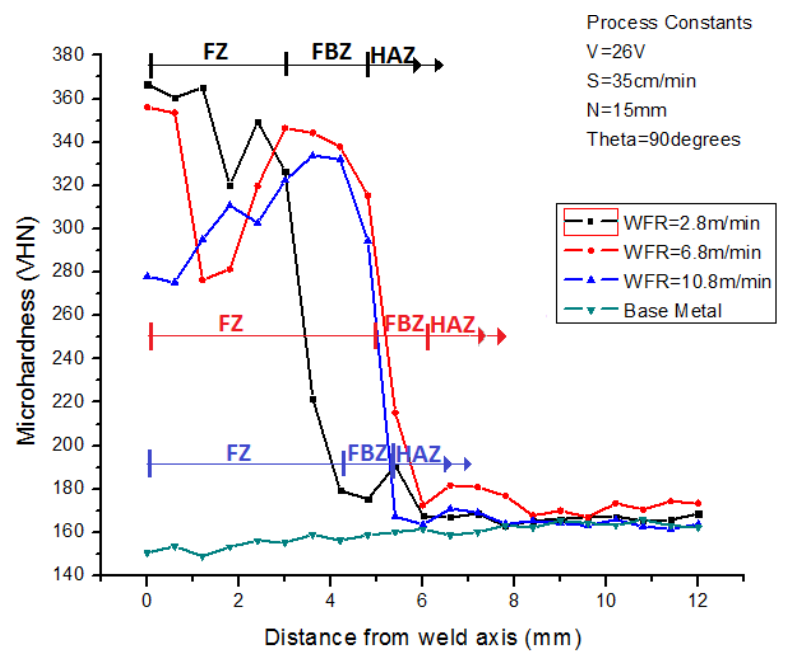

Fig. 3 (a) effect of wire feed rate on microhardness along horizontal axis 


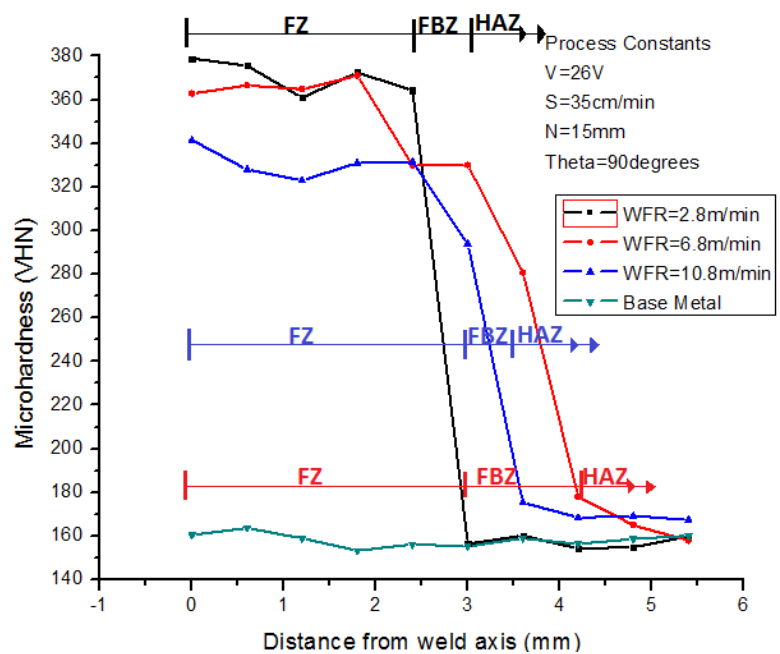

Fig. 3 (b) effect of wire feed rate on microhardness along vertical axis

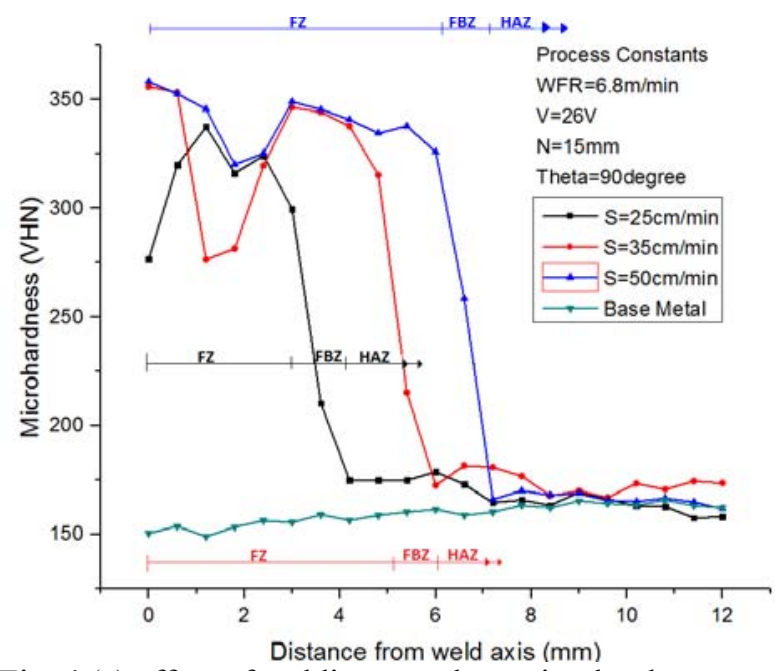

Fig. 4 (a) effect of welding speed on microhardness along horizontal axis

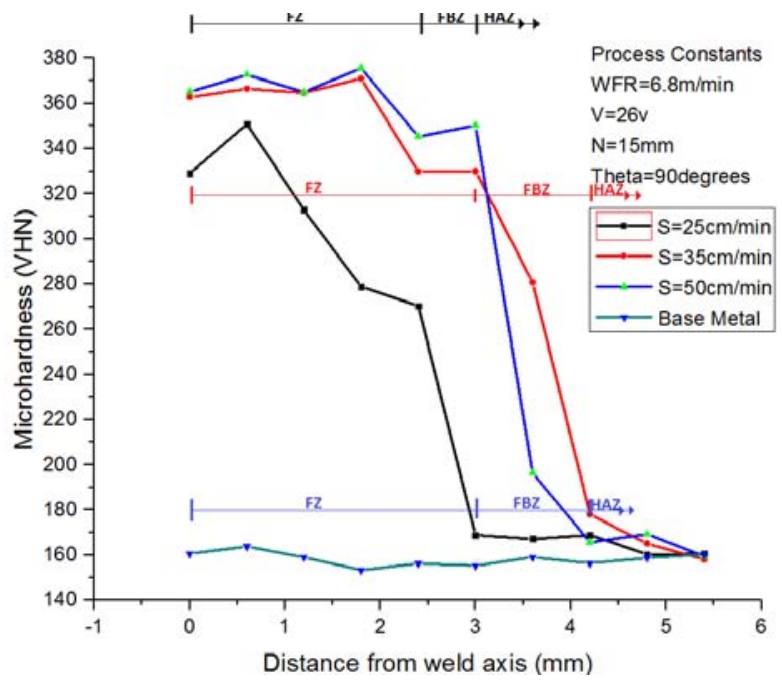

Fig. 4 (b) effect of welding speed on microhardness along vertical axis

At low voltage the average microhardness value is maximum indicating that it was the result of high cooling rate which did not give enough time for the grain growth and hence increased hardness.

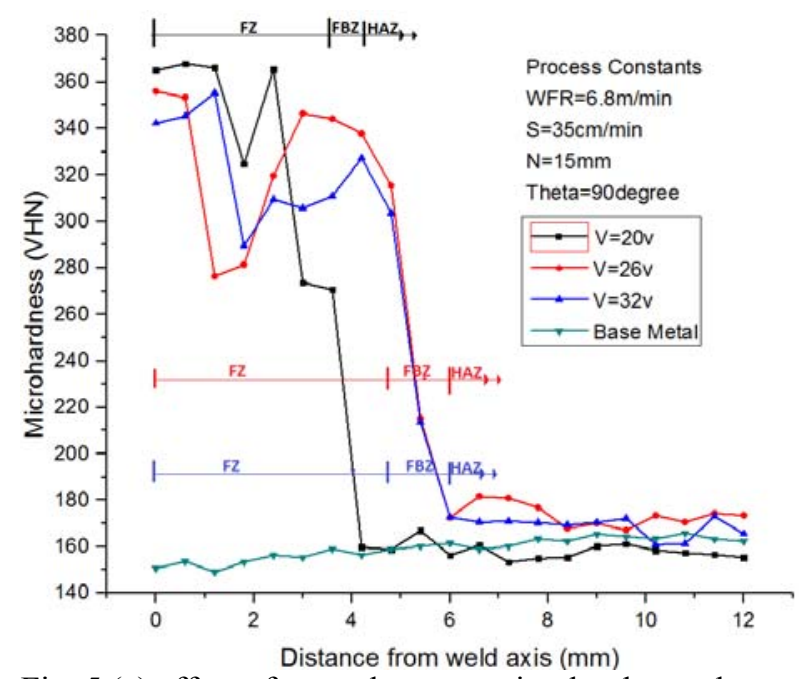

Fig. 5 (a) effect of arc voltage on microhardness along horizontal axis

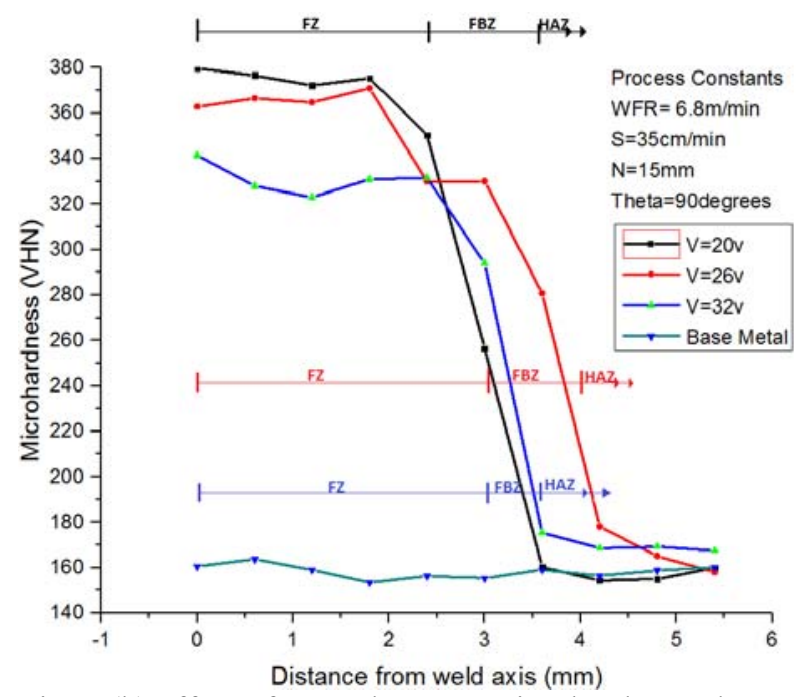

Fig. 5 (b) effect of arc voltage on microhardness along vertical axis

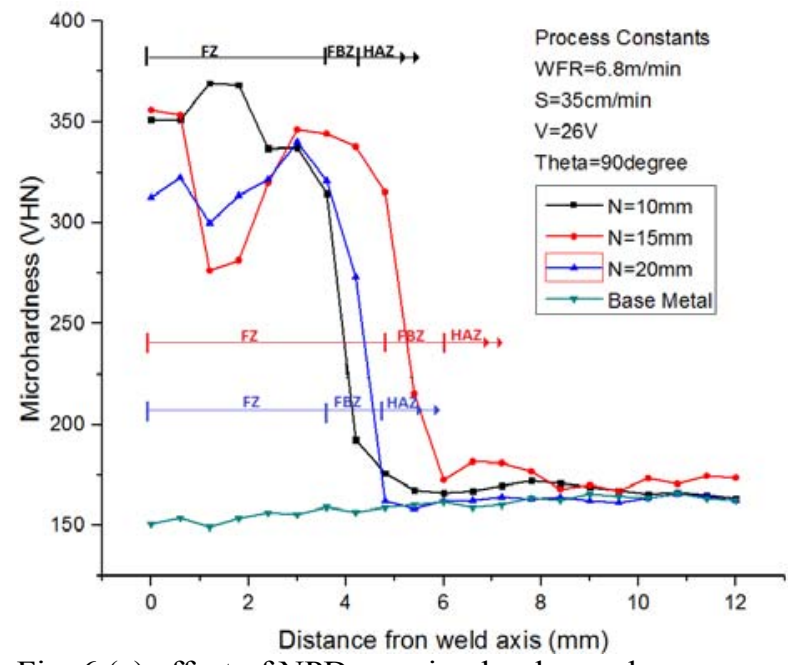

Fig. 6 (a) effect of NPD on microhardness along horizontal axis

\subsection{Effect of nozzle to plate distance}

The effects of change in NPD on microhardness along the vertical axis of the bead are shown in fig. 6 (b). It is evident that at lowest value of NPD the microhardness is maximum and vice-versa. 
The probable reason could be that at maximum NPD the shielding gas experiences maximum spread thereby its cooling effect reduces, resulting in slow cooling rate and hence lower hardness.

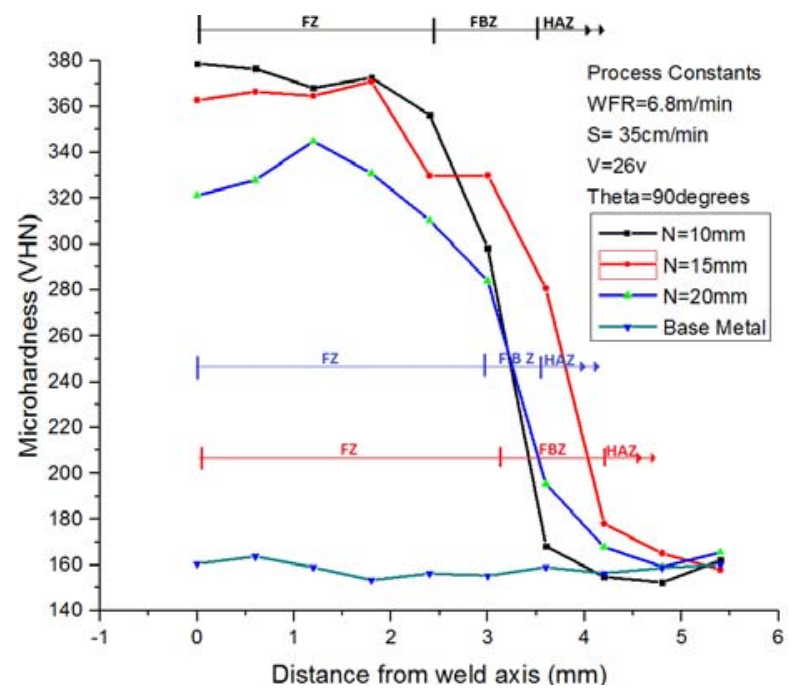

Fig. 6 (b) effect of NPD on microhardness along vertical axis

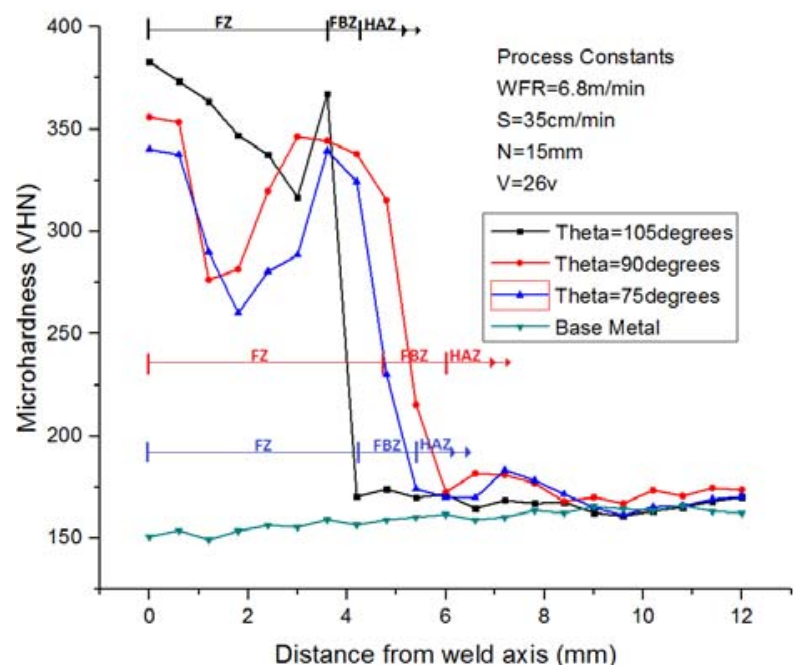

Fig. 7 (a) effect of torch angle on microhardness along horizontal axis

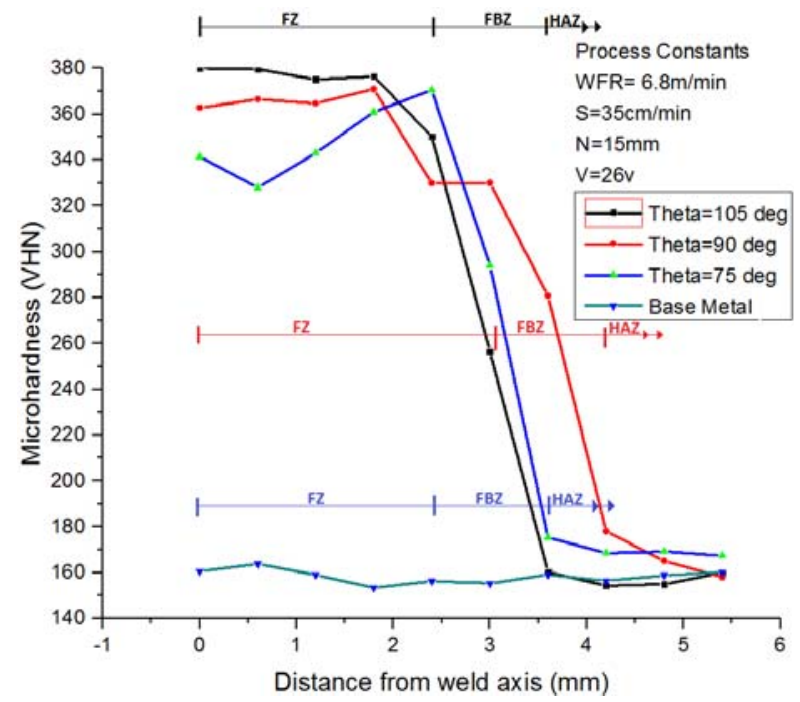

Fig. 7 (b) effect of torch angle on microhardness along vertical axis
Figure 6 (a) shows the variations in microhardness along the horizontal axis. In this case there are excessive fluctuations in microhardness values for all the NPD's. This could probably be due to the changing heat flow patterns possibly caused by changing flow patterns of the shielding gas.

\subsection{Effect of torch angle}

Figure 7 (a) indicates that microhardness of weld metal for torch angle of $105^{\circ}$ i.e. forehand welding was maximum, whereas it was lowest for torch angle $75^{\circ}$ i.e. backhand welding. The reason could be that for forehand welding the cooling rate was maximum and it was minimum for backhand welding. Figure 7 (b) also shows nearly the same trend.

\section{CONCLUSIONS}

The following conclusions can be drawn from the above observations

1. The heat input and cooling rate decide the kind of microstructure formed and resulting microhardness at a given point.

2. Microhardness varied with variations in weld parameters

3. Microhardness was reduced in HAZ probably due to grain growth

4. Microhardness was maximum at minimum WFR

5. Microhardness was maximum at maximum welding speed.

6. Microhardness was maximum at minimum arc voltage.

7. Microhardness was maximum at minimum NPD.

8. Microhardness was maximum at maximum torch angle.

\section{REFERENCES}

[1] Parmar, R. S., "Welding Processes and Technology". Khanna Publishers, $10^{\text {th }}$ edition, New Delhi, 2010.

[2] Rao, C.S., Prasad, K.S and Rao, D.N., "Study on Effect of Welding Speed on Microstructure and Mechanical Properties of Pulse Current Micro Plasma Arc Welded Inconel 625 sheets". Journal of Minerals and Materials characterization and Engineering, Vol. 11, pp. 10271033, 2012.

[3] Pandey, S., Ph.D. Thesis on "Some Studies on MIG Welding of Aluminum and its Alloy 5083". Department of Mechanical Engineering. IIT Delhi, India, 1986.

[4] Davies, A.C., "Welding", Cambridge University Press, $10^{\text {th }}$ edition, UK.

[5] Raveendra, A., Ravi Kumar, B.V.R., "Microhardness and Mechanical Properties of EN-24 Alloy Steel Weldments using Pulsed and Non Pulsed Current Gas Tungsten Arc Welding". International Journal of Innovative Research in Science, Engineering and Technology. Vol. 3, issue 10, pp 16588-16593, October2014.

[6] Kurt, H.I., Samur, R., "Study on Microstructure, Tensile Strength and Hardness of Stainless Steel 316 Joined by TIG Welding". International Journal of Advances in Engineering, Science and Technology. Vol. 3, No.1, pp. 1-6, Feb-April 2013.

Authors: Pradeep Khanna, Associate Professor, Dr. Sachin Maheshwari, Professor, Division of Manufacturing Processes and Automation Engineering, Netaji Subhas Institute of Technology, New Delhi, India, Phone: 91-011-25000200

E-mail: 4.khanna@gmail.com ssaacchhiinn@gmail.com 